American J. of Engineering and Applied Sciences 4 (4): 435-439, 2011

ISSN 1941-7020

(C) 2014 N.N. Atta et al., This open access article is distributed under a Creative Commons Attribution

(CC-BY) 3.0 license

\title{
Effect of Pressure, Water Depth and Water Flow Rate on Oxygen Saturation Level in Activated Sludge Process
}

\author{
Nabil N. Atta, Amro A. Elbaz and Alhassan H. Sakr \\ Department of Environmental Engineering, \\ Faculty of Engineering, Zagazig University, Egypt
}

\begin{abstract}
Problem statement: The role of aeration in activated sludge process is to provide oxygen to microorganisms as they assimilate the organic carbon compounds and digest a portion of them to carbon dioxide and water, sulfate and nitrate compounds. The water aeration equipment used in this process consumes as much as $60-80 \%$ of total power requirements in modern wastewater treatment plants. Approach: The objective of this study is to enhance the oxygen transfer in aeration tank in activated sludge process by increasing pressure inside the part of aeration tank to increase the saturation level of dissolved oxygen in wastewater. The diffuser cap model is the experimental model which was used to show the effect of increasing pressure on oxygen transfer level. Three cases were considered, the first used without diffuser cap, the second with diffuser cap and the third with diffuser cap and plastic strips. Results: Obtained results show that in case of using the model with diffuser cap enhanced the oxygen level by about $5 \%$ than in case of without diffuser cap while that of adding plastic strips enhanced the oxygen level by about $7 \%$. The variation of water flow showed that increasing water flow rate from 1-2 $\mathrm{L} \mathrm{min}^{-1}$ decreased the oxygen saturation level by about $6 \%$. Furthermore, increasing water depth from $15-60 \mathrm{~cm}$ increased the oxygen level by about $40 \%$. Conclusion: The diffuser cap model showed that the increase of pressure and water depth increased the dissolved oxygen level while increasing water flow rate decreased the dissolved oxygen level.
\end{abstract}

Key words: Oxygen saturation, effect of pressure, activated sludge

\section{INTRODUCTION}

Activated sludge is the most widely used biological treatment process. In an activated sludge process, oxygen is usually supplied to the wastewater by diffused aeration or mechanical aeration (Reynolds and Richards, 1996). In diffusing aeration, a diffuser is used to introduce small air bubbles near the bottom of the tank. The air bubble size is kept small for an efficient oxygen transfer to water.

The efficiency of oxygen transfer depends on many factors, including the type, size and shape of the diffuser; the air flow rate; the depth of submersion; tank geometry; and wastewater characteristics (Tchobanoglous et al., 2004). In bubble diffused aeration systems the coefficient of oxygen transfer $\mathrm{K}$ increases with the airflow rate and water temperature, but decreases with the water depth.

Aeration of the wastewater enhances the removal of the Biological Oxygen Demand (BOD), which is the amount of oxygen consumed by the microorganisms in oxidation of the pollutants in wastewater, Nitrogen removal and aerobic sludge treatment.
The cost of aeration comes to more than $50 \%$ of the total energy consumption of the entire treatment process and that could be reduced substantially by using intermittent aeration (Hamamoto et al., 1997; Ferrer et al., 1998; Schuyler, 1997).

Equipment for aeration may be classified into four categories: waterfall aerators, diffusion or bubble aerators, mechanical aerators and pressure aerators. In waterfall aerators, water is spread into droplets or thin films to increase the contact area between water and air. Common waterfall aerators are spray aerators, multiple tray aerators, cascade aerators, cone aerators and packed columns (AWWA, 1998).

Oxygen is an important nutrient that is used by microorganisms for growth, maintenance and metabolite production and scarcity of oxygen affects the process performance (Garcia-Ochoa et al., 2000; Calik et al., 2004; Liu et al., 2006).

Different types of aeration systems have been developed over the years to improve the energy efficiency of oxygen transfer process. The diffuser cap model is the experimental model used for enhancement the oxygen transfer in aeration tank.

Corresponding Author: Amro A. Elbaz, Department of Environmental Engineering, Faculty of Engineering, 


\section{MATERIALS AND METHODS}

The presents study investigates the effect of increasing pressure by using diffuser cap on dissolved oxygen level, in aeration tank as shown in Fig. 1.

The diffuser cap model is the experimental model which is used to show the effect of increasing pressure on dissolved oxygen level. This model was used in three cases, the first case without diffuser cap, the second case with diffuser cap and the third case with diffuser cap and plastic strips.

The apparatus consists of glass basin with dimension $(30 \times 30 \times 100 \mathrm{~cm})$ and a diffuser cap with cubic shape $(29 \times 29 \times 29 \mathrm{~cm})$ was installed inside it. There are four diffusers on the top of diffuser cap and four diffusers at the bottom of diffuser cap. Plastic strip as shown in Fig. 2 is a plastic tube filled with water up to $70 \%$ of its length that was installed inside the apparatus to decrease the rising velocity of rising bubbles.

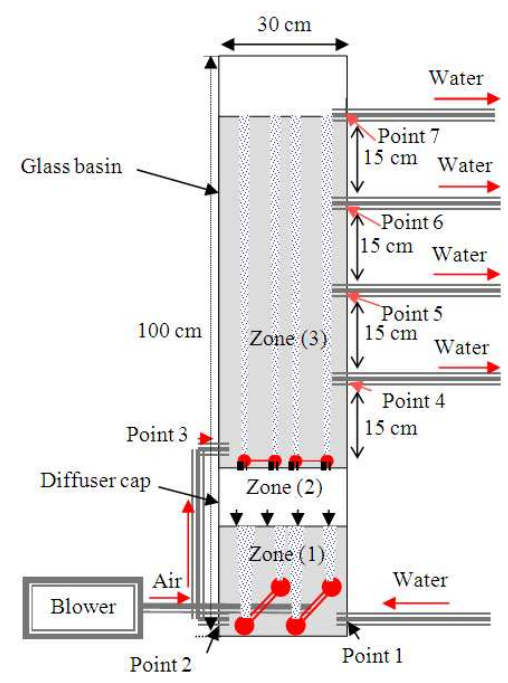

Fig. 1: Schematic of experimental apparatus

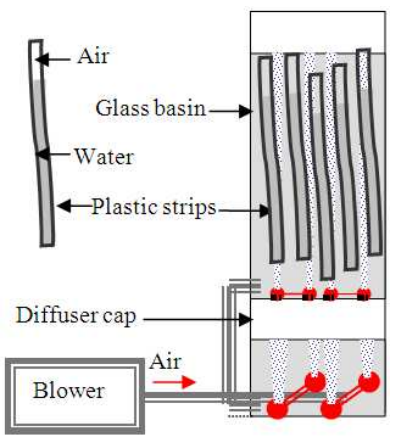

Fig. 2: Plastic strips
A schematic of the experimental system is illustrated in Fig. 1. The air pumped from the blower is introduced into the diffuser cap and passes through four diffusers. Three zones can be distinguished; zone 1, zone 2 and zone 3.

Due to increasing pressure inside diffuser cap as a result of jet aeration zone 1 and zone 2 are formed.

The air rises from zone 1 and inter pressurized air zone 2 and with continuous aeration, zone 2 is increased and zone 1 is decreased.

After certain time, the volume of each two zones become constant due to the balance of two forces, one is resulting from air flow rate pressure and the other resulting from water flow rate pressure. The pressurized air leaves zone 2 and passes through four diffusers within four vents and enter zone 3 rising up to the surface of water.

Water enters in the diffuser cap zone 1 from point 1 and outflow from diffuser cap from point 2 . Due to the pressure inside the diffuser cap, the water flows from diffuser cap from point 2 and enters zone 3 from point 3 .

\section{RESULTS}

It can be shown from Fig. 3-5 that using diffuser cap enhances the oxygen mass transfer.

The variation of water depths and water flow rates affects the oxygen mass transfer level. Figure 3 shows that at water flow rate $1 \mathrm{~L} \mathrm{~min}^{-1}$ and water depth $15 \mathrm{~cm}$, the dissolved oxygen level in the case of using diffuser cap increased from $6.49 \mathrm{mg} \mathrm{L}^{-1}$ (in the case without using diffuser cap) to reach the level of $6.9 \mathrm{mg} \mathrm{L}^{-1}$ and by adding plastic strips dissolved oxygen increased to the level of $7.02 \mathrm{mg} \mathrm{L}^{-1}$. The measured pressure at this depth was $790 \mathrm{mmHg}$.

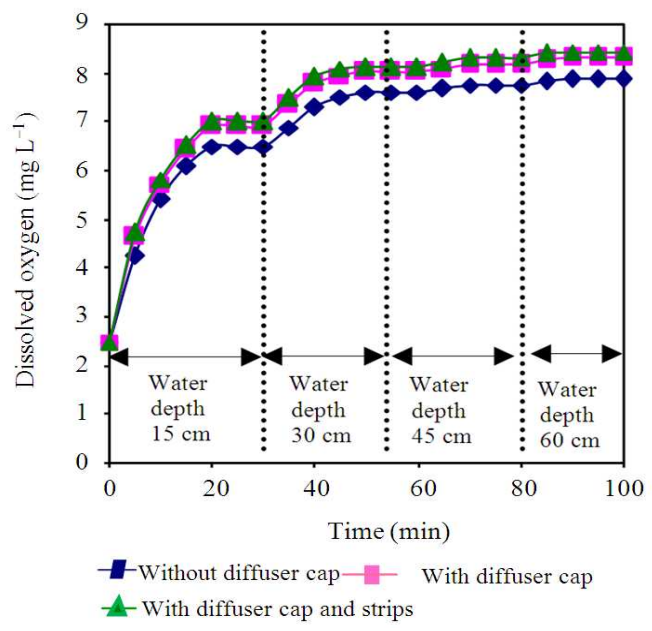

Fig. 3: Dissolved oxygen level at water flow rate $1 \mathrm{~L}$ $\min ^{-1}$ 
Am. J. Engg. \& Applied Sci., 4 (4): 435-439, 2011

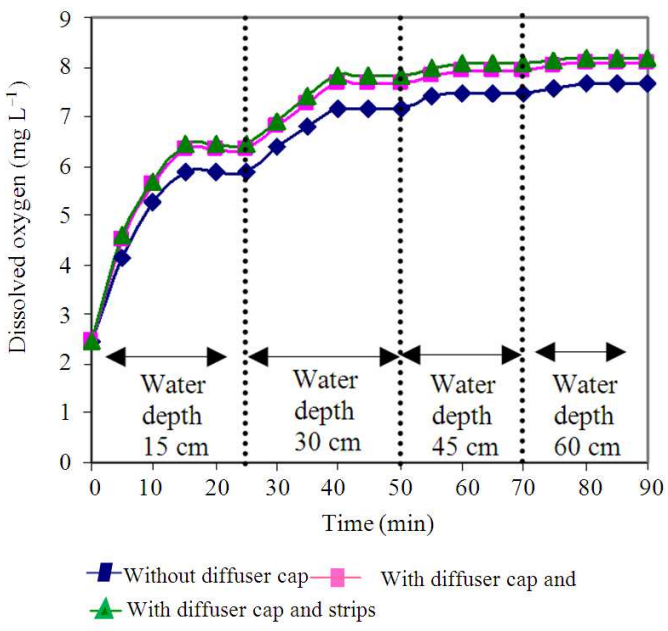

Fig. 4: Dissolved oxygen level at water flow rate $1 \mathrm{~L} \mathrm{~min}^{-1}$

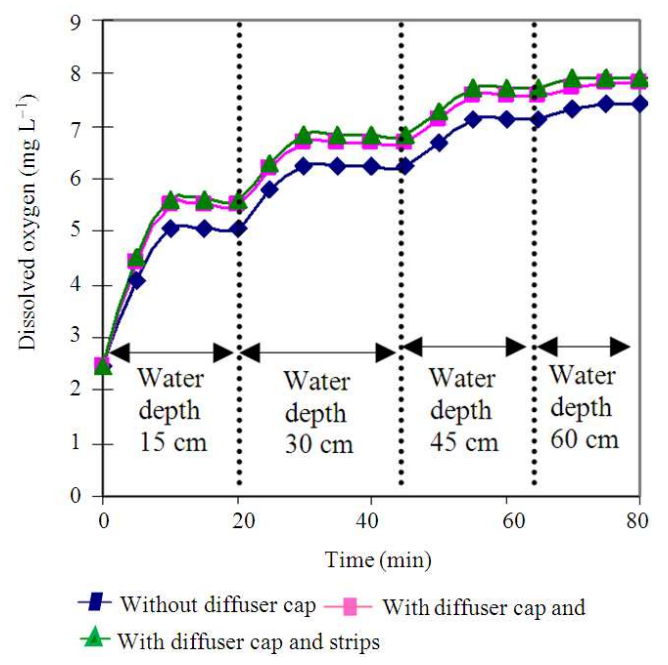

Fig. 5: Dissolved oxygen level at water flow rate $1 \mathrm{~L}$ $\min ^{-1}$

At water depth $30 \mathrm{~cm}$, the dissolved oxygen level in the case of using diffuser cap increased from 7.61 $\mathrm{mg} / \mathrm{lit}$ (in the case without using diffuser cap) to reach the level of $8.01 \mathrm{mg} \mathrm{L}^{-1}$ and by adding plastic strips dissolved oxygen increased to the level of $8.13 \mathrm{mg} \mathrm{L}^{-1}$. The measured pressure at this depth was $800 \mathrm{mmHg}$.

At water depth $45 \mathrm{~cm}$, the dissolved oxygen level in the case of using diffuser cap increased from $7.76 \mathrm{mg}$ $\mathrm{L}^{-1}$ (in the case without using diffuser cap) to reach the level of $8.17 \mathrm{mg} \mathrm{L}^{-1}$ and by adding plastic strips dissolved oxygen increased to the level of $8.31 \mathrm{mg} \mathrm{L}^{-1}$. The measured pressure at this depth was $810 \mathrm{mmHg}$.
Table 1: Comparing dissolved oxygen level at water flow rate $1 \mathrm{~L} \mathrm{~min}^{-1}$

\begin{tabular}{llll}
\hline $\begin{array}{l}\text { Water } \\
\text { depth }\end{array}$ & $\begin{array}{l}\mathrm{DO}\left(\mathrm{L} \mathrm{min}^{-1}\right) \\
\text { without } \\
\text { diffuser cap }\end{array}$ & $\begin{array}{l}\mathrm{DO}\left(\mathrm{L} \mathrm{min}^{-1}\right) \\
\text { with } \\
\text { diffuser cap }\end{array}$ & $\begin{array}{l}\mathrm{DO}(\mathrm{L} \mathrm{min} \\
\text { with diffuser } \\
\text { cap and strips }\end{array}$ \\
\hline 15 & 6.49 & 6.9 & 7.02 \\
30 & 7.61 & 8.01 & 8.13 \\
45 & 7.76 & 8.17 & 8.31 \\
60 & 7.88 & 8.31 & 8.43 \\
\hline
\end{tabular}

Table 2: Comparing dissolved oxygen level at water flow rate $1.5 \mathrm{~L} \mathrm{~min}^{-1}$

\begin{tabular}{lllc}
\hline $\begin{array}{l}\text { Water } \\
\text { depth }\end{array}$ & $\begin{array}{l}\text { DO }\left(\mathrm{mg} \mathrm{L}^{-1}\right) \\
\text { without } \\
\text { diffuser cap }\end{array}$ & $\begin{array}{l}\text { DO }\left(\mathrm{mg} \mathrm{L}^{-1}\right) \\
\text { with } \\
\text { diffuser cap }\end{array}$ & $\begin{array}{l}\text { DO }\left(\mathrm{mg} \mathrm{L}^{-1}\right) \\
\text { with diffuser } \\
\text { cap and strips }\end{array}$ \\
\hline 15 & 5.88 & 6.33 & 6.43 \\
30 & 7.18 & 7.66 & 7.80 \\
45 & 7.49 & 7.92 & 8.07 \\
60 & 7.66 & 8.07 & 8.19 \\
\hline
\end{tabular}

At water depth $60 \mathrm{~cm}$, the dissolved oxygen level in the case of using diffuser cap increased from $7.88 \mathrm{mg}$ $\mathrm{L}^{-1}$ (in the case without using diffuser cap) to reach the level of $8.31 \mathrm{mg} \mathrm{L}^{-1}$ and by adding plastic strips dissolved oxygen increased to the level of $8.43 \mathrm{mg} / \mathrm{lit}$. The measured pressure at this depth was $820 \mathrm{mmHg}$

As shown in Table 1 the results obtained at water flow rate $1 \mathrm{~L} \mathrm{~min}^{-1}$ and at various depths $15,30,45$ and $60 \mathrm{~cm}$. The dissolved oxygen level increased with increasing depth and the range of increase was about $20 \%$.

Figure 4 shows that at water flow rate $1.5 \mathrm{~L} \mathrm{~min}^{-1}$ and water depth $15 \mathrm{~cm}$ the dissolved oxygen level in the case of using diffuser cap increased from $5.88 \mathrm{mg} \mathrm{L}^{-1}$ (in the case without using diffuser cap) to reach the level of $6.33 \mathrm{mg} \mathrm{L}^{-1}$ and by adding plastic strips dissolved oxygen level increased to the level of $6.43 \mathrm{mg} \mathrm{L}^{-1}$.

At water depth $30 \mathrm{~cm}$ the dissolved oxygen level in the case of using diffuser cap increased from $7.18 \mathrm{mg} \mathrm{L}^{-1}$ (in the case without using diffuser cap) to reach the level of $7.66 \mathrm{mg} \mathrm{L}^{-1}$ and by adding plastic strips dissolved oxygen level increased to the level of $7.8 \mathrm{mg} \mathrm{L}^{-1}$.

At water depth $45 \mathrm{~cm}$ the dissolved oxygen level in the case of using diffuser cap increased from $7.49 \mathrm{mg} \mathrm{L}^{-1}$ (in the case of without using diffuser cap) to reach the level of $7.92 \mathrm{mg} \mathrm{L}^{-1}$ and by adding plastic strips dissolved oxygen level increased to the level of $8.07 \mathrm{mg} \mathrm{L}^{-1}$.

At water depth $60 \mathrm{~cm}$ the dissolved oxygen level in the case of using diffuser cap increased from $7.66 \mathrm{mg}$ $\mathrm{L}^{-1}$ (in the case of without using diffuser cap) to reach the level of $8.07 \mathrm{mg} \mathrm{L}^{-1}$ and by adding plastic strips dissolved oxygen increased to the level of $8.19 \mathrm{mg} \mathrm{L}^{-1}$.

As shown in Table 2 the results obtained at water flow rate $1.5 \mathrm{~L} \mathrm{~min}^{-1}$ and at various depths 15, 30, 45 and $60 \mathrm{~cm}$. The dissolved oxygen level increased with increasing depth the range of increase was about $27 \%$. 
Am. J. Engg. \& Applied Sci., 4 (4): 435-439, 2011

\begin{tabular}{llll}
\multicolumn{3}{l}{ Table 3: } & Comparing dissolved oxygen level at water flow rate 2 $\mathrm{L} \mathrm{min}^{-1}$ \\
\hline $\begin{array}{l}\text { Water } \\
\text { depth } \\
(\mathrm{cm})\end{array}$ & $\begin{array}{l}\text { DO without } \\
\text { diffuser cap } \\
\left(\mathrm{mg} \mathrm{L}^{-1}\right)\end{array}$ & $\begin{array}{l}\text { DO with } \\
\text { diffuser } \\
\text { cap }\left(\mathrm{mg} \mathrm{L}^{-1}\right)\end{array}$ & $\begin{array}{l}\text { DO with } \\
\text { diffuser cap } \\
\text { and strips }\left(\mathrm{mg} \mathrm{L}^{-1}\right)\end{array}$ \\
\hline 15 & 5.07 & 5.51 & 5.62 \\
30 & 6.27 & 6.71 & 6.83 \\
45 & 7.11 & 7.57 & 7.72 \\
60 & 7.41 & 7.80 & 7.94
\end{tabular}

Figure 5 shows that at water flow rate $2 \mathrm{~L} \mathrm{~min}^{-1}$ at water depth $15 \mathrm{~cm}$. The dissolved oxygen level in case of using diffuser cap increased from $5.07 \mathrm{mg} \mathrm{L}^{-1}$ (in the case of without using diffuser cap) to reach the level of $5.51 \mathrm{mg} \mathrm{L}^{-1}$ and by adding plastic strips dissolved oxygen increased to the level of $5.62 \mathrm{mg} \mathrm{L}^{-1}$.

At water depth $30 \mathrm{~cm}$ the dissolved oxygen level in case of using diffuser cap increased from $6.27 \mathrm{mg} \mathrm{L}^{-1}$ (in the case of without using diffuser cap) to reach the level of $6.71 \mathrm{mg} \mathrm{L}^{-1}$ and by adding plastic strips dissolved oxygen level increased to the level of $6.83 \mathrm{mg} \mathrm{L}^{-1}$.

At water depth $45 \mathrm{~cm}$ the dissolved oxygen level in the case of using diffuser cap increased from $7.11 \mathrm{mg} \mathrm{L}^{-1}$ (in the case of without using diffuser cap) to reach the level of $7.57 \mathrm{mg} \mathrm{L}^{-1}$ and by adding plastic strips dissolved oxygen level increased to the level of $7.72 \mathrm{mg} \mathrm{L}^{-1}$.

At water depth $60 \mathrm{~cm}$ the dissolved oxygen level in the case of using diffuser cap increased from $7.41 \mathrm{mg}$ $\mathrm{L}^{-1}$ (in the case of without using diffuser cap) to reach the level of $7.8 \mathrm{mg} \mathrm{L}^{-1}$ and by adding plastic strips dissolved oxygen level increased to the level of $7.94 \mathrm{mg} \mathrm{L}^{-1}$.

Table 3 shows the results at water flow rate $2-\mathrm{L}$ $\min ^{-1}$ and at various water depths $15,30,45$ and $60 \mathrm{~cm}$. The dissolved oxygen level increased with increasing depth the range of increase was about $40 \%$.

\section{DISCUSSION}

The results from experimental study show that at depth $0.45 \mathrm{~m}$ the oxygen transfer efficiency is 3.87 and at depth $0.60 \mathrm{~m}$ the oxygen transfer efficiency is 4.2 .

A similar trend was observed by Al-Ahmady (2006) who showed that the increasing the depth of diffuser increase the oxygen transfer efficiency of the system. At $0.4 \mathrm{~m}$ the oxygen transfer efficiency is 1.8 and the oxygen transfer efficiency increase to 11.5 at the depth of diffuser equal to $4.6 \mathrm{~m}$.

This result showed also that using diffuser cap enhanced the oxygen transfer efficiency since the oxygen transfer coefficient Kla increased by about 25 $\%$ more than in case of without using diffuser cap and in case of using diffuser cap and plastic strips, the oxygen transfer coefficient Kla increased by about $36 \%$ more than in case of without using diffuser cap.

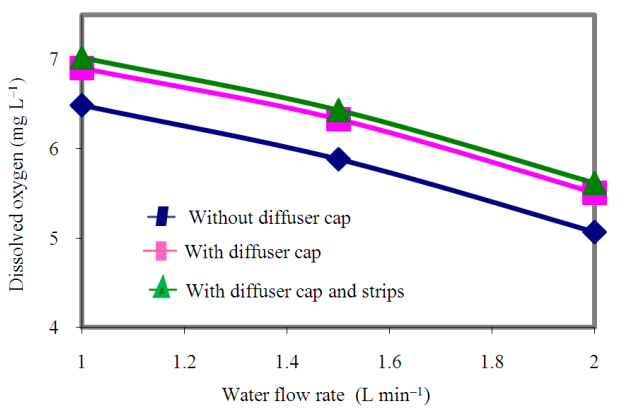

Fig. 6: DO at water depth $15 \mathrm{~cm}$

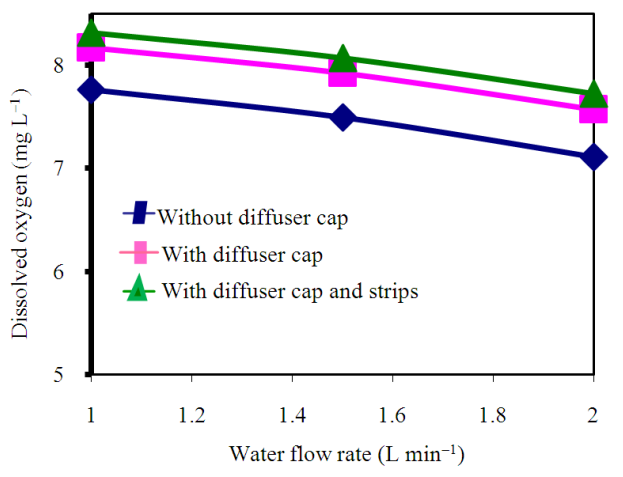

Fig. 7: DO at water depth $60 \mathrm{~cm}$

Furthermore, a similar trend was observed by Kim and $\mathrm{Ra}$ (2005) who studied the effect of slant plate and use covered basin to enhance the oxygen transfer coefficient Kla show that by adding only the slant plate into the standard aeration basin, the oxygen transfer coefficient Kla increased about by $15 \%$ higher than that of standard aeration basin. Additionally, in the water surface contacting cover system the oxygen transfer coefficient improved about $25 \%$ on the lab-scale aeration basin.

By installing the cover plate and slant plate, the Kla could improve about $40 \%$, compared to the standard aeration basin.

It can be noticed from Table 4 that the dissolved oxygen level was decreased with time by increasing water flow rate. This decrease is attributed to the decrease of retention time with the increase of flow rate.

The effect of variation of water flow rate from 1 , 1.5 and $2 \mathrm{~L} \mathrm{~min}^{-1}$ on dissolved oxygen level is shown in Fig. 6 and 7 at depths of water $15 \mathrm{~cm}$ and $60 \mathrm{~cm}$ over diffuser cap respectively. It can be noticed from Fig. 6 that at depth $15 \mathrm{~cm}$, when increasing flow rate from 1$1.5 \mathrm{~L} \mathrm{~min}^{-1}$ in case of using diffuser cap, the value of dissolved oxygen level decreased by about $8 \%$ On the other hand when increasing flow rate from 1-2 $\mathrm{L} \mathrm{min}^{-1}$, dissolved oxygen level decreased by about $25 \%$. 
Am. J. Engg. \& Applied Sci., 4 (4): 435-439, 2011

Table 4: Comparing dissolved oxygen at various water depths and various water flow rate

\begin{tabular}{lllll}
\hline $\begin{array}{l}\text { Water } \\
\text { flow rate } \\
\left(\mathrm{L} \mathrm{min}^{-1}\right)\end{array}$ & $\begin{array}{l}\text { Water } \\
\text { depth } \\
(\mathrm{cm})\end{array}$ & $\begin{array}{l}\text { DO without } \\
\text { diffuser cap } \\
\left(\mathrm{mg} \mathrm{L}^{-1}\right)\end{array}$ & $\begin{array}{l}\text { DO with } \\
\text { diffuser } \\
\text { cap }\left(\mathrm{mg} \mathrm{L}^{-1}\right)\end{array}$ & $\begin{array}{l}\text { DO with } \\
\text { diffuser cap } \\
\text { and strips }\left(\mathrm{mg} \mathrm{L}^{-1}\right)\end{array}$ \\
\hline 1 & 15 & 6.49 & 6.9 & 7.02 \\
& 60 & 7.88 & 8.31 & 8.43 \\
1.5 & 15 & 5.88 & 6.33 & 6.43 \\
& 60 & 7.66 & 8.07 & 8.19 \\
2 & 15 & 5.07 & 5.51 & 5.62 \\
& 60 & 7.41 & 7.8 & 7.94 \\
\hline
\end{tabular}

By increasing the water depth from $15-60 \mathrm{~cm}$ as shown in Fig. 7. It can be noticed that at depth 60, when increasing flow rate from 1-1.5 $\mathrm{L} \mathrm{min}^{-1}$ in case of using diffuser cap, the value of dissolved oxygen decreased by about $3 \%$. On the other hand when increasing flow rate from 1-2 $\mathrm{L} \mathrm{min}^{-1}$, dissolved oxygen level decreased by about $6 \%$.

From the previous discussion it can be noticed that the dissolved oxygen level was decreased when increasing flow rate from 1-2 $\mathrm{L} \mathrm{min}^{-1}$ while the dissolved oxygen level was increased by increasing water depth from 15-60 cm over diffuser cap.

\section{CONCLUSION}

Changing the operating conditions in aeration process can affect the aeration performance. Many conditions can be varied such as water flow rate and depth of water.

From this research study it is shown that the diffuser cap model shows that increasing pressure by about $4 \%$ causes an increase in oxygen level by about $5 \%$ at water flow rate $1 \mathrm{~L} \mathrm{~min}^{-1}$ and water depth $60 \mathrm{~cm}$ over diffuser cap.

The oxygen mass transfer rate in first 20 min was very high compared with the following $60 \mathrm{~min}$ and the level of oxygen mass transfer was reduced near the saturation point of oxygen so; the increase of saturation point of oxygen by increasing pressure helps to increase the oxygen mass transfer.

Due to variation of water flow rate from 1-2 L $\min ^{-1}$, the dissolved oxygen level was reduced by $6 \%$ at water depth $60 \mathrm{~cm}$ over diffuser cap.

Changing the water depth can affect the rate of the dissolved oxygen level in which the increase of depth from $15-60 \mathrm{~cm}$ at water flow rate $2 \mathrm{~L} \mathrm{~min}^{-1}$ increased the dissolved oxygen level by $40 \%$.

\section{ACKNOWLEDGEMENT}

The researchers would like to acknowledge the help of Dr. Diaa Elmonairy the former head of Environmental Engineering Department, Faculty of Engineering, Zagazig University, Egypt.

\section{REFERENCES}

Al-Ahmady, K.K., 2006. Analysis of oxygen transfer performance on sub-surface aeration systems. Int. J. Environ. Res. Public Health, 3: 301-308. PMID: 16968978

AWWA, 1998. Water Treatment Plant Design. 3rd Edn., McGraw-Hill, New York, ISBN: 10: 0070016437, pp: 806.

Calik, P., P. Yilgora, P. Ayhanb and A.S. Demir, 2004. Oxygen transfer effects on recombinant benzaldehyde lyase production. Chem. Eng. Sci., 59: 5075-5083. DOI: 10.1016/j.ces.2004.07.070

Ferrer, J., M.A. Rodrigo, A. Seco and J.M. Penya-roja, 1998. Energy saving in the aeration process by fuzzy logic control. Water Sci. Technol., 38: 209217. DOI: $10.1016 / \mathrm{S} 0273-1223(98) 00463-6$

Garcia-Ochoa, F., E.G. Castro and V.E. Santos, 2000. Oxygen transfer and uptake rates during xanthan gum production. Enzyme Microb. Technol ., 27: 680-690. DOI: 10.1016/S0141-0229(00)00272-6

Hamamoto, Y., S. Tabata and Y. Okubo, 1997. Development of the intermittent cyclic process for simultaneous nitrogen and phosphorus removal. Water Sci. Technol., 35: 145-152. DOI: 10.1016/S0273-1223(96)00890-6

Kim, Y.K. and D.G. Ra, 2005. Water surface contacting cover system-the basic study for improving the oxygen transfer coefficient and the BOD removal capacity. Water Res., 39: 1553-1559. DOI: 10.1016/j.watres.2004.09.031

Liu, Y.S., J.Y Wu and K.P. Ho, 2006. Characterization of oxygen transfer conditions and their effects on Phaffia rhodozyma growth and carotenoid production in shake-flask cultures. Biochem. Eng. J., 27: 331-335. DOI: 10.1016/j.bej.2005.08.031

Reynolds, T.D. and P.A. Richards, 1996. Unit Operations and Processes in Environmental Engineering. 2nd Edn., PWS Publishing, Boston, ISBN: 10: 0534948847, pp: 798.

Schuyler, R.O., 1997. On/off aeration saves money and improves effluent quality. Fuel Energy Abst., 38: 443-443.

Tchobanoglous, G., F.L. Burton and H.D. Stensel, 2004. Wastewater Engineering: Treatment and Reuse. 4th Edn., McGraw-Hill, London, New York, ISBN: 007124140X, pp: 1819. 